\title{
EVALUATION OF BULK ORGANIC CARBON ISOTOPE RECORDS FROM EARLY PALEOGENE STRATA IN THE HANNA BASIN (WYOMING, U.S.A.) SPANNING THE PALEOCENE- EOCENE THERMAL MAXIMUM
}

JAMES CHISHOLM, Department of Geological Sciences, California State University, San Bernardino Research Advisor: Joan E. Fryxell

\section{INTRODUCTION}

The early Paleogene was dominated by a global greenhouse climatic state punctuated by abrupt, transient warming events known as hyperthermals (McInerney and Wing, 2011). These hyperthermals were each less than 200,000 years long and were associated with perturbations in the global carbon cycle (McInerney and Wing, 2011). The perturbations are manifested as negative excursions in stable carbon isotope records from proxies hosted in both marine and nonmarine strata (McInerney and Wing, 2011). The Paleocene-Eocene Thermal Maximum (PETM) was the largest of these events and occurred approximately 56 million years ago (McInerney and Wing, 2011). Although identified at many locations within marine strata, there exist only a few locations in nonmarine strata where the climatic event has been identified (McInerney and Wing, 2011). This study sought to extend the geographic range of these localities by developing a bulk organic carbon isotope record from early Paleogene strata in the Hanna Basin of south-central Wyoming.

Bulk organic $\delta^{13} \mathrm{C}$ values capture an average value of organic matter, mostly plant debris, preserved in sedimentary rock (Benner et al., 1987; Wynn et al.,2006; Wynn, 2007). These carbon isotope values are useful for tracking changes in the isotopic composition of atmospheric $\mathrm{CO}_{2}$ as well as a range of ecophysiological conditions experienced by plants. This includes water stress, photosynthetic pathway, and plant type (Farquhar et al., 1980, 1989; Arens et al., 2000; Jahren et al., 2008; Diefendorf et al., 2010; Kohn, 2010). Additionally, post-mortem alteration of bulk organic $\delta^{13} \mathrm{C}$ values can occur due to mixing with refractory, allochthonous carbon and various diagenetic modifications as the organic matter experiences higher pressures and temperatures at depth (Benner et al., 1987; Wynn et al., 2006; Wynn, 2007; Baczynski et al., 2013; 2016). Thus, bulk organic $\delta^{13} \mathrm{C}$ records tend to be "noisy" relative to other carbon isotope records such a n-alkanes, marine carbonates, and pedogenic carbonates (McInerney and Wing, 2011). However, bulk organic $\delta^{13} \mathrm{C}$ values have successfully identified the PETM in nonmarine strata in previous studies (Magioncalda et al., 2008; Foreman et al., 2012; Baczynski et al., 2013, 2016), and bulk organic $\delta^{13} \mathrm{C}$ proxies are particularly useful when thick accumulations of nonmarine strata (in excess of 100 meters) must be assessed to identify the 200 kyr PETM interval.

The PETM has been linked with the massive release of isotopically light, exogenic carbon into the atmosphere and oceans (McInerney and Wing, 2011). However, the source of this isotopically light carbon is still uncertain. Various researchers have proposed volcanic emissions, meteorite impacts, mantle degassing, extreme forest fires, widespread permafrost oxidation, and the release of methane clathrates (McInerney and Wing. 2011). The release of methane clathrates is currently the most favored hypothesis, but it is difficult to rectify this carbon source with the magnitude of shallowing of the carbonate compensation depth in the ocean and the observed warming (McInerney and Wing. 2011). Constraining the true magnitude of the isotopic excursion and carbon source or sources 
is critical in determining the climate's sensitivity to fluctuations in $p \mathrm{CO}_{2}$ (McInerney and Wing 2011). Having additional data from multiple geographic areas will yield a more accurate understanding of the carbon cycle perturbation and allows us to evaluate how local environmental conditions before, during, or after the PETM may have changed. The Western Interior of the United States is a particularly good location to undertake such a project as a series of intermontane basins preserve early Paleogene strata deposited during the Laramide Orogeny. The PETM has been identified in three of these basins, and in two of these three the PETM is identified in bulk organic $\delta^{13} \mathrm{C}$ values as well as other proxies (Magioncalda et al., 2004; Foreman et al., 2012; Baczynski et al., 2013; 2016).

\section{GEOLOGIC BACKGROUND}

This study focuses on a bulk organic carbon isotope record derived from the early Paleogene Hanna Formation in the Hanna Basin of south-central Wyoming (Fig. 1). The Hanna Basin is a Laramide structural basin formed during the Laramide Orogeny

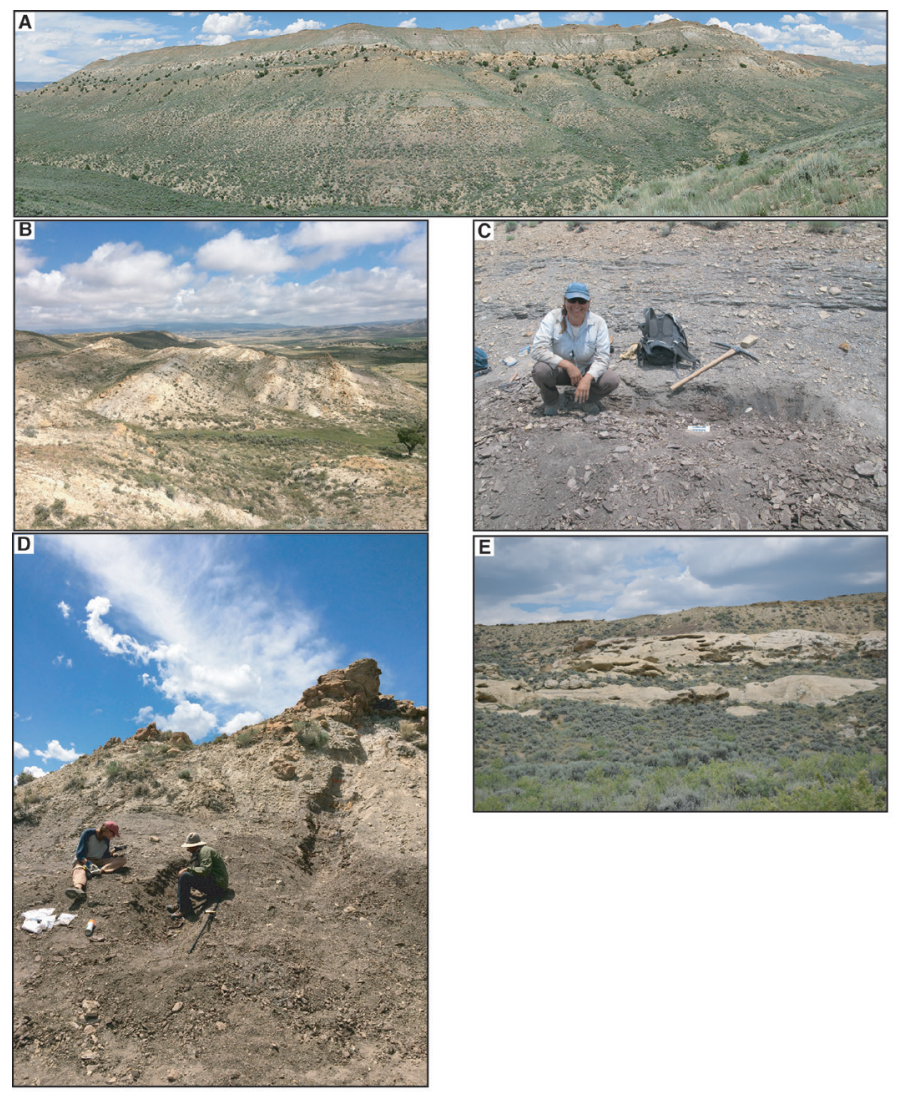

Figure 1. Field photographs of two stratigraphic sections, A) Hanna Draw and B) Hanna Breaks, C) overbank coal unit, D) overbank depositional cycle, and E) fluvial sandbody. in the Late Cretaceous through early Paleogene (Dickinson et al., 1988). The basin is surrounded by various basement involved uplifts including the Rawlins Uplift to the west, the Medicine Bow Mountains to the south, and the Seminoe-ShirleyFreezeout Hills mountains to the north. The Hanna Basin is anomalous in the thickness of accumulated strata amongst Laramide basins, preserving in excess of 12,000 meters of Cambrian through Miocene strata (Wroblewski, 2002). The early Paleogene Hanna Formation is approximately 3500 meters of this total. The Hanna Formation spans deposition from approximately $62 \mathrm{Ma}$ to at least $54 \mathrm{Ma}$ based on scattered mammal fossils, palynology, and $\mathrm{U}-\mathrm{Pb}$ detrital zircon geochronologic maximum depositional ages (Wroblewski, 2003 and references therein; Dechesne et al., in review). The depositional environments within the Hanna Formation are diverse, and include fluvial, lacustrine, palustrine, and swamp lithofacies associations (Lillegraven and Snoke, 1996; Secord, 1998; Wroblewski, 2002; Dechesne et al., in review). Within the stratigraphic interval of focus in this study thick, laterally continuous fluvial sandbodies are present as well as a variety of organicrich overbank facies above Coal 82 of Dobbin et al. (1929). The large fluvial sandbody ("Big Channel" in Fig. 1) was traced laterally by Dechesne et al. (in review) to the Hanna Breaks area, where our second stratigraphic section is located.

\section{METHODS}

Two stratigraphic sections were measured, one near the basin center called Hanna Draw and one towards the northeast margin called Hanna Breaks (Fig. 1). Sections were measured using standard Jacob's staff and Brunton compass methods and corrected for local strike and dip of the strata (originally measured by Dechesne et al., in review). The Hanna Draw section was a total of 285 meters thick, and the Hanna Breaks section was a total of 488 meters thick. The sections were trenched using hand tools to expose fresh sedimentary rock for standard lithofacies descriptions (e.g., grain size, sorting, bed contacts, sedimentary structures). Fist-sized samples of rock were obtained from trenched sections, wrapped in aluminum foil, and labeled with their stratigraphic height for carbon isotope analyses. In total 403 samples were obtained 
from the Hanna Draw section representing an average spacing of every 0.7 meters. In the Hanna Breaks section, a total of 222 samples were obtained for an average spacing of 2.2 meters. However, in each section the stratigraphic spacing of samples varies due to outcrop limitations and an increase in sampling density in proximity to the Paleocene-Eocene boundary.

Samples were prepared for isotopic analysis by grinding each sample using a mortar and pestle into a fine powder. This is followed by removing any carbonate phases in the samples (diagenetic or cements) whose $\delta^{13} \mathrm{C}$ values can greatly differ from organic $\delta^{13} \mathrm{C}$ values. Approximately 1 gram of powder was loaded into labeled vials and subjected to an acid treatment. Initially, $30 \mathrm{~mL}$ of $0.5 \mathrm{M} \mathrm{HCl}$ was added, the sample sealed and mixed using a vortex mixer. The sample was allowed to react for 12 hours, prior to centrifuging and decanting of reacted acid. This step was repeated a second time, and each sample reacted for a total of 24 hours. Finally, the sample was rinsed four times using deionized water using the same mix, centrifuging, and decanting process. After the rinsing steps the samples were dried in a freeze-dryer under a vacuum. The dry samples were then weighed (between 0.27 and $50.00 \mathrm{mg}$ depending on expected $\% \mathrm{C}$ content) in tin capsules. This overall preparation method is similar that applied by Magioncalda et al. (2004) and Baczynski et al. (2013; 2016). The Total Organic Carbon composition and the isotopic values were analyzed at UC Davis Stable Isotope Facility using an elemental analyzer (Elementar Vario EL Cube) interfaced with a continuous flow isotope ratio mass spectrometer (PDZ Europa 20-20), and precision/accuracy assessed using internal standards $( \pm 0.2 \%)$. All data are reported in standard deltanotation relative to VPDB. Replicates of samples in the Hanna Draw section $(\mathrm{n}=50)$ display $\delta^{13} \mathrm{C}$ values within $0.40 \%$ $\pm 0.6(1 \sigma)$ of one another on average and a median offset of $0.2 \%$. Replicates of unknown samples in Hanna Breaks section $(\mathrm{n}=75)$ display $\delta^{13} \mathrm{C}$ values within $0.3 \%$ o $\pm 0.2(1 \sigma)$ with median offsets of $0.2 \%$.

\section{RESULTS}

Figures 2 and 3 show the up-section variability in carbon isotope stratigraphy. $\delta^{13} \mathrm{C}$ values have an average of $-27.3 \% \neq \pm 1.5 \%$ ( $(1 \sigma)$ in the Hanna Draw section and an average of $-26.8 \% 0 \pm 1.1 \%$ in the Hanna Breaks section. Both sections show a large spread in $\delta^{13} \mathrm{C}$ values, with Hanna Draw ranging from $-31.8 \%$ to $-21.4 \%$ (10.4\%o range) and Hanna Breaks from $-29.8 \%$ to $-20.1 \%$ ( $9.8 \%$ range). Most lithologies display variations in $\delta^{13} \mathrm{C}$ values, of less than $1.5 \%$ standard deviation in each stratigraphic section. However, the sandstones at Hanna Draw have an unusually high standard deviation of $2.55 \%$. When $\delta^{13} \mathrm{C}$ values and $\% \mathrm{C}$ are plotted against one another for each section there does not seem to be a correlation between them, as indicated by very low $\mathrm{R}^{2}$

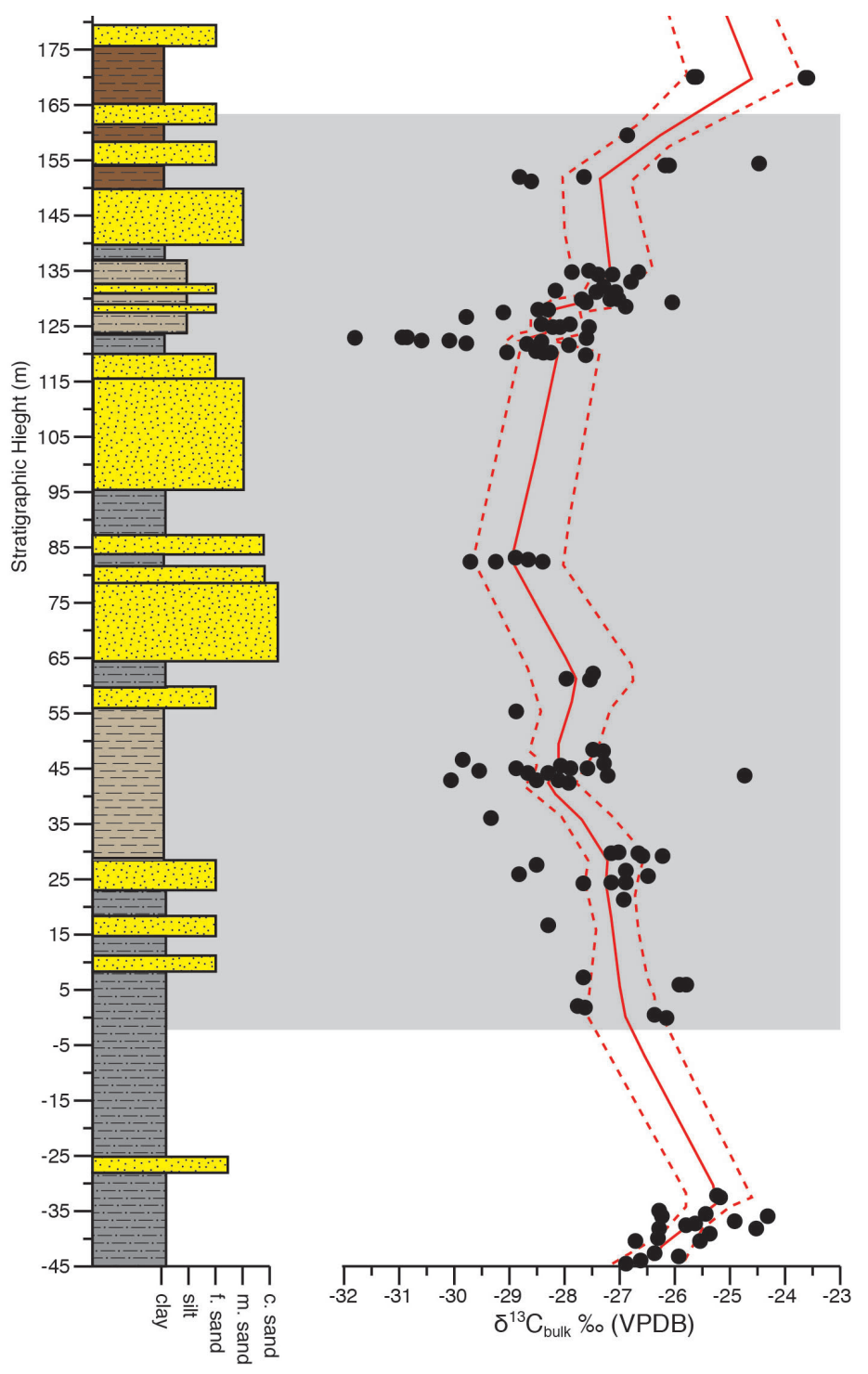

Fig. 2. Carbon isotope record through the Hanna Draw stratigraphic section. Red line is a LOESS smoothing average and dashed red line a 95\% confidence interval. Grey zone demarks PETM interval. 


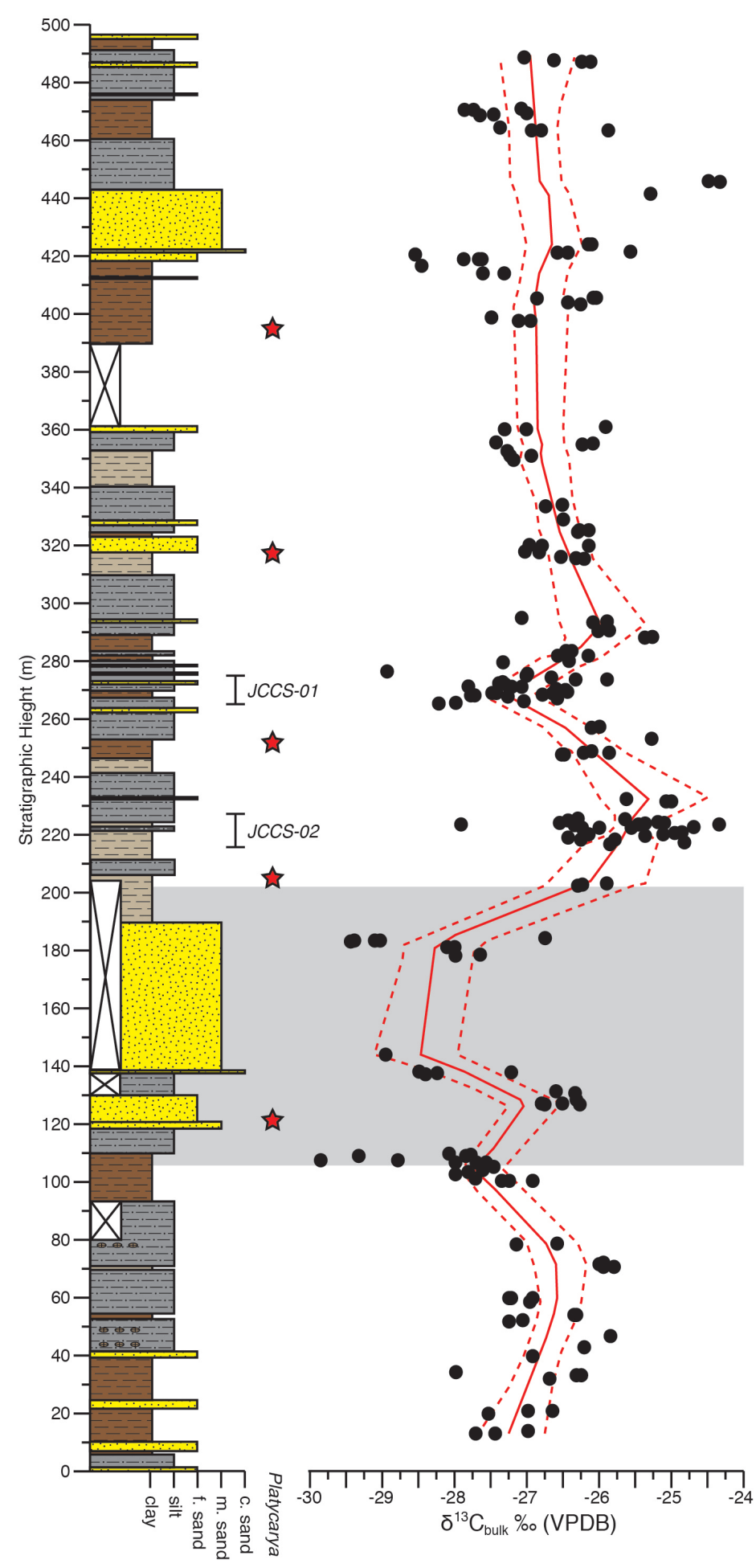

Fig. 3. Carbon isotope record through the Hanna Breaks stratigraphic section. Red line is a LOESS smoothing average and dashed red line a 95\% confidence interval. Grey zone demarks PETM interval.

values of 0.11 and 0.008 for each stratigraphic section respectively (Fig. 4).

In each of the stratigraphic sections there is a high amount of variability in $\delta^{13} \mathrm{C}$ values (Figs. $2 \& 3$ ), but also structure to the carbon isotope records up-section. In the Hanna Draw area $\delta^{13} \mathrm{C}$ values from the -40 to $0 \mathrm{~m}$ stratigraphic range from $-24.3 \%$ to $-26.8 \%$. Then the $\delta^{13} \mathrm{C}$ value begin to decrease in the following 60 $\mathrm{m}$ to a lowest value of $-30.1 \%$ at $42.75 \mathrm{~m}$. This is then followed up by a large fluvial sand body. At the 120 -meter level, $\delta^{13} \mathrm{C}$ values starts to increase again up to the 180 -meter level where the highest value of $\delta^{13} \mathrm{C}$ is $-21.42 \%$ is achieved at $159.75 \mathrm{~m}$.

In the Hanna Breaks section between 0 and 100 meters $\delta^{13} \mathrm{C}$ values range from $-25.8 \%$ to $-28.0 \%$. Over the next ten meters, carbon isotope values decrease, with the lowest value in the section $(-29.8 \%$ o ) occurring at 107.6 meters. This decrease is approximately five meters below the first major sandstone unit, after which carbon isotope values remain low, although variable (the most positive value in the section, $-20.1 \%$ also occurs at $126.4 \mathrm{~m}$ ), until the 183.92-meter level when $\delta^{13} \mathrm{C}$ values increase again. Above 200 $\mathrm{m}$, carbon isotope values become higher, with most values ranging from $-24.3 \%$ o to $-28.0 \%$, but typically isotopically higher than those stratigraphically associated with the large fluvial sandbody.

The amount of organic carbon $(\% \mathrm{C})$ has an average of $5.7 \% \pm 12.7 \%$ in Hanna Draw and $2.9 \% \pm 4.7 \%$ in Hanna Breaks. Hanna Draw shows both greater variation and amount of $\% \mathrm{C}$. The major control on $\% \mathrm{C}$ appears to be lithology. Coals and shales contain higher amounts of $\% \mathrm{C}$. Whereas the rest of Hanna Draw lithologies display significantly less $\% \mathrm{C}$ in comparison, sandstones contain the least amount of $\% \mathrm{C}$. In the Hanna Breaks section $\% \mathrm{C}$ shows a similar pattern. All \%C have a relatively low standard

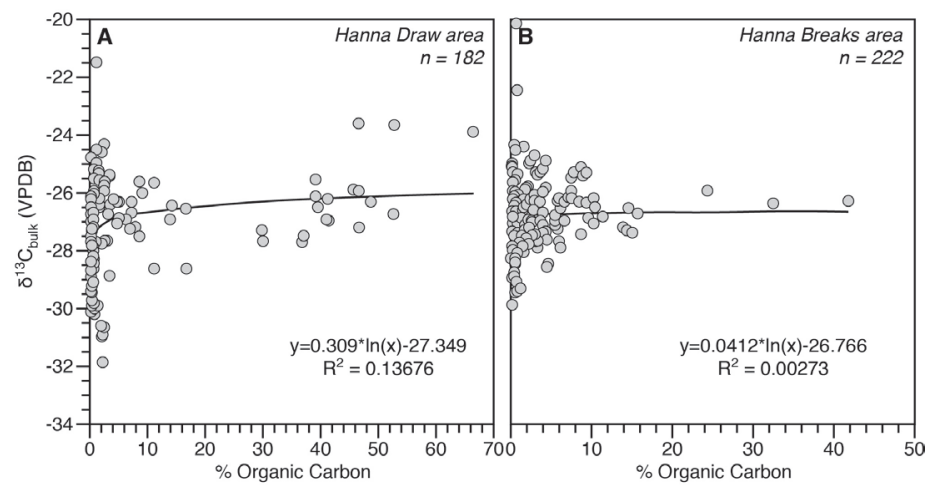

Fig. 4. Relationship between carbon isotope value and percent carbon at Hanna Draw (A) and Hanna Breaks (B). 
deviation in comparison to the Hanna Draw and only shale has large $\% \mathrm{C}$ values. Sandstone continues to have the lowest values of $\% \mathrm{C}$.

\section{DISCUSSION \& CONCLUSIONS}

\section{$\delta^{13} \mathrm{C}$ Variability}

$\delta^{13} \mathrm{C}$ can be influenced by several factors that could lead to variability in the data. Photosynthetic pathways (i.e., C3 versus C4) can affect $\delta^{13} \mathrm{C}$ values by $14 \%$ o causing data to overlap (O'Leary, 1988). However, only $\mathrm{C} 3$ photosynthesis plants were dominant in the Paleocene with $\mathrm{C} 4$ dominantly appearing in the Miocene (Cerling et al., 1993). This is further supported by $\delta^{13} \mathrm{C}$ values only being in the ranges of expected $\mathrm{C} 3$ photosynthesis of $-33 \%$ o to $-24 \%$ o (O'Leary, 1988). Water stress and plant functional type (e.g., angiosperm versus gymnosperm) can also influence $\delta^{13} \mathrm{C}$ values (Diefendorf et al., 2010; Kohn, 2010). Greater water stress leads to higher $\delta^{13} \mathrm{C}$ values in plants and gymnosperms tend to exhibit lower $\delta^{13} \mathrm{C}$ values than evergreen angiosperms (Diefendorf et al., 2010; Kohn, 2010). The only major change in precipitation/hydrologic change and vegetation overturn currently known in the Laramide region during the latest Paleocene is associated with the PETM itself (Wing et al., 2005). Both factors would be expected to produce a protracted increase in $\delta^{13} \mathrm{C}$ values. This is not observed in the data. Instead greater than $1 \%$ of variability is observed over short stratigraphic intervals, sometimes even within a single bed or replicate samples. This suggests that something other than widespread hydrologic and vegetation changes are controlling $\delta^{13} \mathrm{C}$ values. Preservation and diagenesis of plant matter present in our samples could also be the source of this $\delta^{13} \mathrm{C}$ variation. By comparing the $\delta^{13} \mathrm{C}$ and $\% \mathrm{C}$ and determining their relationship we can see if $\% \mathrm{C}$ is contributing to the change in $\delta^{13} \mathrm{C}$. As diagenetic alteration occurs and increases a logarithmic relationship wherein decreases in $\% \mathrm{C}$ and higher $\delta^{13} \mathrm{C}$ values should develop (Benner et al., 1987; Wing et al., 2005; Wynn et al., 2006; Wynn, 2007). Figure 4 illustrates the relationship between the two data sets, showing no strong relationship between $\delta^{13} \mathrm{C}$ and $\% \mathrm{C}$. Thus, most of the small-scale variability in $\delta^{13} \mathrm{C}$ values appears to be stochastic in character.

\section{Identification of PETM}

The PETM is an abrupt global warming event, less than $200 \mathrm{kyrs}$, and is preserved in marine records in a few stratigraphic meters (McInerney and Wing, 2011). In nonmarine strata its stratigraphic thickness can reach to over 40 meters (Magioncalda et al., 2004; Foreman et al., 2012). The greater thickness in nonmarine strata is likely related to higher overall sedimentation and subsidence rates. However, identifying the PETM is still nontrivial and requires additional chronostratigraphic constraints in addition to the aforementioned negative carbon isotope excursion. These commonly include magnetostratigraphic constraints, radiometric dates, and biostratigraphic constraints such as mammal and pollen fossils. Recently, colleagues have constrained the base of the Eocene within the Hanna Formation using the presence of Platycarya, an early Eocene indicator pollen taxa (Dechesne et al., in review). The first appearance of this Eocene indicator essentially co-occurs with the negative carbon isotope excursion observed in both our stratigraphic sections (Fig. 2 \& $3)$. This strongly suggests this is the PETM, and it is bolstered by maximum depositional ages of $\sim 54 \mathrm{Ma}$ from $\mathrm{U}-\mathrm{Pb}$ ages from detrital zircons stratigraphic higher in the column (Dechesne et al., in review).

The magnitude of the excursion is between $\sim 2 \%$ o to 4\% in the Hanna Draw and Hanna Breaks sections. This compares well with the typical size of the PETM excursion magnitude from a variety of nonmarine bulk organic $\delta^{13} \mathrm{C}$ values, which range from $2.2 \%$ to $4.6 \%$ (McInerney \& Wing, 2011). The size of the excursion in the Hanna Formation is roughly the same as it is in the Bighorn Basin (Magioncalda et al., 2004) and Piceance Creek Basin (Foreman et al., 2012) to the north and south of the Hanna Basin. Interestingly, these two basins are dominated by red-bed paleosol development and well-drained conditions on the floodplain. These depositional environments are the opposite of those observed in the Hanna Formation, which indicate poorly drained, wet floodplains. The size of the magnitude is approximately the same in all three basins, but the baseline, absolute $\delta^{13} \mathrm{C}$ values are lower in the Hanna Formation by 1-2\%o. This offset is likely due to reduced water stress within the Hanna Formation as compared to the other basins (Kohn, 
2010).

\section{ACKNOWLEDGEMENTS}

This material is based upon work supported by the Keck Geology Consortium and the National Science Foundation under Grant No. 1659322, as well as NSF grant EAR 145031 to Ellen Currano. I would also like to thank my fellow Keck researchers for assistance in the field, Christine Shonnard, Jake Polsak, Keifer Nace, Anthony Semararo, and Xavier Nogueira, project directors Ellen Currano and Brady Foreman, scientific collaborators Marieke Dechesne and Regan Dunn, and my campus advisor Joan Fryxell.

\section{REFERENCES}

Baczynski, A.A., McInerney, F.A., Wing, S.L., Kraus, M.J., Bloch, J.I., Boyer, D.M., Secord, R., Morse, P.E., Fricke, H.C. 2013. Chemostratigraphic implications of spatial variation in the PaleoceneEocene Thermal Maximum carbon isotope excursion, SE Bighorn Basin, Wyoming. Geochemistry, Geophysics, Geosystems, 14: 4133-4152.

Baczynski, A.A., McInerney, F.A., Wing, S.L., Kraus, M.J., Morse, P.E., Bloch, J.I., Chung, A.H., Freeman, K.H. 2016. Distortion of carbon isotope excursion in bulk soil organic matter during the Paleocene-Eocene thermal maximum. GSA Bulletin 128: 1352-1366.

Benner, R., Fogel, M.L., Sprague, E.K., Hodson, R.E. 1987. Depletion of ${ }^{13} \mathrm{C}$ in lignin and its implications for stable isotope studies. Nature 327, 708-710.

Cerling, W.T., Quade Y.J. 1993. Global ecological change in the late Miocene: expansion of $\mathrm{C} 4$ ecosystems Nature 361: 344-345.

Dechesne, M., Currano, E.D., Dunn, R.E., Higgins, P., Hartman, J.H., Chamberlain, K.R., HolmDenoma, C.S. in review, Geosphere. Depositional patterns of the fluvial to paludal strata of the Hanna Formation across the Paleocene-Eocene boundary, Hanna Basin, Wyoming.
Diefendorf, A.F., Mueller, K.E., Wing, S.L., Koch, P.L., Freeman, K.H. 2010. Global patterns in leaf ${ }^{13} \mathrm{C}$ discrimination and implications for studies of past and future climate. PNAS 107: 5738-5743.

Dobbin, C. E., Bowen, C. F., Hoots, H. W. 1929. Geology and coal and oil resources of the Hanna and Carbons basins, Carbon County, Wyoming. U.S. Geological Survey Bulletin 804: 88 p.

Foreman B., Clementz M.T., Heller P.L. 2012. Evaluation of paleoclimatic conditions east and west of the southern Canadian Cordillera in the mid-late Paleocene using bulk organic $\delta^{13} \mathrm{C}$ records. Palaeogeography, Palaeoclimatology, Palaeoecology 376: 103-113.

Jahren, A.H., Arens, N.C., Harbeson, S.A., 2008. Prediction of atmospheric $\delta^{13} \mathrm{CO}_{2}$ using fossil plant tissues. Reviews of Geophysics 46, RG1002.

Koch, P. 1998. Isotopic reconstruction of past continental environments. Annual Reviews of Earth and Planetary Sciences 26: 573-613.

Kohn, M.J., 2010. Carbon isotope compositions of terrestrial C3 plants as indicators of (paleo) ecology and (paleo)climate. PNAS 107: 1969119695.

Lillegraven, J.A., Snoke, A.W. 1996. A new look at the Laramide orogeny in the Seminoe and Shirley mountains, Freezeout Hills, and Hanna Basin, south-central Wyoming. Wyoming State Geological Survey Public Information Circular no. 36,52 p.

Magioncalda, R., Dupuis, C., Smith, T., Steurbaut, E., Gingerich, P., 2004. Paleocene-Eocene carbon isotope excursion in organic carbon and pedogenic carbonate: direct comparison in a continental stratigraphic section. Geology 32: 553-556.

McInerney,F., Wing, S. 2011. The Paleocene-Eocene thermal maximum: a perturbation of carbon cycle, climate, and biosphere with implications 
for the future. Annual Reviews of Earth and Planetary Sciences 39: 489-516.

Midwood, A.J., Boutton, T.W., 1998, Soil carbonate decomposition by acid has little effect on $\delta^{13} \mathrm{C}$ of organic matter. Soil Biology and Biochemistry 30(10/11): 1301-1307.

O’Leary, M.H., 1988. Carbon isotopes in photosynthesis. BioScience 38: 328-336.

Secord, R. 1998. Paleocene mammalian biostratigraphy of the Carbon Basin, southeastern Wyoming, and age constraints on local phases of tectonism. Rocky Mountain Geology 33: 119154.

Wynn, J.G. 2007. Carbon isotope fractionation during decomposition of organic matterin soils and paleosols: implications for paleoecological interpretation of paleosols. Palaeogeography, Palaeoclimatology, Palaeoecology 251: 437-448.

Wynn, J.G., Bird, M.I., Wong, V.N.L. 2005. Rayleigh distillation and the depth profile of ${ }^{13} \mathrm{C} /{ }^{12} \mathrm{C}$ ratios of soil organic carbon from soils of disparate texture in Iron Range National Park, Far North Queensland, Australia. Geochimica et Cosmochimica Acta 69: 1961-1973.

Wynn, J.G., Harden, J.W., Fries, T.L. 2006. Stable carbon isotope depth profiles and soil organic carbon dynamics in the lower Mississippi Basin. Geoderma 131: 89-109.

Wing, S.L., Harrington, G.J., Smith, F.A., Bloch, J.I., Boyer, D.M., Freeman, K.H. 2005. Transient floral change and rapid global warming at the Paleocene-Eocene boundary. Science 310(5750): 993-996.

Wroblewski, A. 2002. The Role of the Hanna Basin in Revised Paleogeographic Reconstructions of the Western Interior Sea During the CretaceousTertiary Transition. Wyoming Geological Association Guidebook. 2002 Field Conference, p. 17-40. 